\title{
STATISTICAL CORRELATION BETWEEN SOCIOECONOMIC INDICATORS AND PROTECTED NATURAL AREAS AROUND THE WORLD
}

\author{
Ricardo Elói de Araújo $^{2 *}$ •, Helder Antônio da Silva ${ }^{2}$ and Geraldo Majela Moraes Salvio² $\odot$
}

\begin{abstract}
${ }^{1}$ Received on 27.04.2021 accepted for publication on 28.09.2021.
${ }^{2}$ Instituto Federal de Educação Ciência e Tecnologia do Sudeste de Minas Gerais, Barbacena, MG - Brasil. E-mail: <reloi76@yahoo.com. br>,<helder.silva@iffudestemg.edu.br>and < geraldo.majela@ifsudestemg.edu.br>.

*Corresponding author.
\end{abstract}

\begin{abstract}
Protected natural areas are important for nature conservation. Nevertheless, some critiques point out that establishing and managing these areas may inhibit socioeconomic development and generate poverty. However, this strategy has presented varying results since some studies show positive effects on human development. The use of development indicators such as the Gross Domestic Product, the Human Development Index, the Gini Index, and the World Happiness Index can favor the understanding of how PNA management and goals may influence human development. This study aimed to correlate the existence of protected natural areas registered in the World Database on Protected Areas with the variables Gross Domestic Product, Human Development Index, Gini Index, and World Happiness Index of each country involved in the research. The correlations were tested for 145 countries through a non-parametric Spearman test. The correlation between the Gross Domestic Product and protected natural area percentage was positive yet nonsignificant. The correlation between the Human Development Index and protected natural area percentage was positive and significant. As for the correlation between the Gini Index and protected natural area percentage, it was negative although non-significant. Regarding the correlation between the World Happiness Index and protected natural area percentage, it was also negative but non-significant. These results are possibly due to situational differences among the countries assessed. It is suggested that future studies such as this one be carried out by economically similar countries or regions to better elucidate the links between protected natural areas and socioeconomic development.
\end{abstract}

Keywords: HDI; IGini; Nature conservation.

\section{CORRELAÇÃO ESTATÍSTICA ENTRE INDICADORES SOCIOECONÔMICOS E AREAS NATURAIS PROTEGIDAS NO MUNDO}

\begin{abstract}
RESUMO-As Áreas Naturais Protegidas são importantes para a conservação da natureza. Entretanto, algumas críticas ponderam que o estabelecimento e gestão destas podem inibir o desenvolvimento socioeconômico e gerar pobreza. Entretanto, esta estratégia tem apresentado resultados divergentes, pois existem estudos demonstrando consequências positivas ao desenvolvimento humano. A utilização de indicadores de desenvolvimento como o Produto Interno Bruto, o Índice de Desenvolvimento Humano, o Índice de Gini e o Índice Mundial de Felicidade pode favorecer a compreensão de como a gestão e os objetivos das Áreas Naturais Protegidas podem influenciar o desenvolvimento humano. Este trabalho objetivou correlacionar a existência das Áreas Naturais Protegidas constantes no Banco de Dados Mundial sobre Áreas Protegidas com o Produto Interno Bruto, Índice de Desenvolvimento Humano, Índice de Gini e Índice Mundial da Felicidade de cada país envolvido na pesquisa. As correlações foram testadas através do teste não paramétrico de Spearman, utilizando dados de 145 países. A correlação entre o percentual de Areas Naturais Protegidas e o Produto Interno Bruto foi positiva, mas não significativa. A correlação entre o percentual de Áreas Naturais Protegidas e o Índice de Desenvolvimento Humano foi positiva e significativa. Já a correlação entre o percentual de Áreas Naturais Protegidas e óndice de Gini foi negativa, porém, não foi significativa. Quanto à correlação entre o percentual de Áreas Naturais Protegidas e o Índice Mundial da Felicidade, esta também foi negativa, mas não significativa. Estes resultados se devem possivelmente às diferenças conjunturais entre os países envolvidos na pesquisa. Sugere-se que estudos como este sejam realizados por países ou regiões economicamente parecidas para uma melhor compreensão da ligação entre a gestão de áreas protegidas e o desenvolvimento socioeconômico.
\end{abstract}

Palavras-Chave: IDH; IGini; Conservação da natureza.

Silf $(c)) E Y$
Revista Árvore 2022;46:e4601 http://dx.doi.org/10.1590/1806-908820220000001 


\section{INTRODUCTION}

A protected natural area (PNA) is a geographical space with clearly defined boundaries that is acknowledged, managed, and dedicated, through legal means or other effective means, to reach longterm goals of nature conservation while also ensuring the maintenance of ecosystem services and associated cultural values (Dudley, 2008). PNAs can vary in size, management, typology, and property depending on the country.

PNA creation and implementation are important in situ nature conservation strategies, responsible for the maintenance of biodiversity and natural resources (Adams et al., 2004). Despite their importance, some critics argue that PNA establishment and management can inhibit local or regional development and, besides failing to meet conservation goals, drive local populations into poverty, because environmental restrictions can preclude the maintenance of traditional practices needed for the subsistence of the peoples that used to occupy the protected land or its surroundings (Diegues, 2001; Colchester, 2010).

On the other hand, PNA establishment has presented varying results. Some studies have shown that PNA establishment on different continents, countries, and regions can have positive socioeconomic consequences by generating income and stimulating regional and local development (Andam et al., 2010; Ferraro et al., 2011; Canavire-Bacarreza and Hanauer, 2013). PNAs generate income by supporting and promoting sustainable tourism programs, cooperatives of eco-friendly products, and encouraging educational activities and scientific research (Araújo, 2007). On average, they contribute to reducing poverty as much as they contribute to reducing deforestation rates (Leverington et al., 2010; Ferraro et al., 2011).

Andam et al. (2010) found that, although communities near PNAs in Costa Rica and Thailand are substantially poorer than the countries' national averages, such observation does not support the hypothesis that inequality owes to the existence of PNAs. Several studies have shown that the net impact of environmental protection reduces poverty. In Brazil and other countries, PNAs allow local, regional, and national development, contributing significantly to both the local subsistence of human populations and environmental conservation (Zambrano et al., 2010;
Medeiros and Young, 2011; Naughton-Treves et al., 2011; Stevenson et al., 2013).

Other studies have also contributed to eradicate the myth that nature conservation is a hurdle for socioeconomic growth. For instance, Oldekop et al. (2016) showed that PNAs with positive socioeconomic results were more likely to have positive conservation results when they adopted co-management regimes, training the locals, reducing economic disparities, and maintaining cultural and subsistence benefits. Pawlewicz et al. (2017) noted that the Nature 2000 network (N2K) does not significantly influence investment attractiveness in Polish territorial units, which could help to mitigate social conflicts that emerge following the establishment of N2K sites. Zeeshan et al. (2017) observed that the socioeconomic status of human settlers around the Keoladeo National Park in India improved after reconciling the community's interests with the governance strategy and through changes in resource utilization in the park, considered an internationally relevant humid zone recognized both as a Ramsar site and a World Heritage site by UNESCO. Chechina et al. (2018) noted through a community-level analysis that communities that depend upon a forest reserve in the Philippines have higher socioeconomic status due to greater access to natural resources.

An alternative to mitigate social conflicts generated by PNA establishment is payment for environmental services (PES). Silveira-Junior et al. (2020) found that PES can effectively contribute to conflict resolution. However, PES results differed among the study cases due to certain attributes such as local environmental conditions, local economic activities, and stakeholder involvement capacity. The authors concluded that joint PES strategies are needed to improve efficiency throughout the PNA management process, from diagnosis to decisionmaking stages.

Coupling environmental conservation and economic development is possible. For instance, Strassburg et al. (2014) found that the current productivity levels of cultivated pastures in Brazil fall between 32 and $34 \%$ of their full potential. According to these authors, raising these figures between 49 and $52 \%$ of their potential should be enough to meet meat consumption demands until the year 2040, without the need to convert natural ecosystems into new

Revista Árvore 2022;46:e4601 
pastures or to expand the agricultural frontier. Also, in a comprehensive report on the implications of nature protection on several economic sectors (including agriculture, silviculture, fishing, and the conservation sector itself), more than 100 economists and scientists found that the global economy would benefit from a $30 \%$ increase in PNA extents in terrestrial and marine areas (Campaign for Nature, 2020). Analyzing the environmental Kuznets curve, Tritsch and Arvor (2016) verified that socioeconomic growth does not seem to be a driver of deforestation in the Brazilian Amazon past the curve's inflection point. The authors also highlighted that the areas subjected to active deforestation in 2010 present lower socioeconomic indicators than stabilized areas. The environmental Kuznets curve posits a relationship between carbon emissions and income in an inverted U-shape. At the initial stages of economic growth, income and emissions have a direct relationship. But as income grows and reaches a certain level, emissions present a downward trajectory. This is because higher-income populations are willing to couple economic growth with lower environmental degradation (Ávila and Diniz, 2015).

Some studies have aimed to relate socioeconomic development with PNAs. Hebron (2018) conducted a bivariate regression analysis using 2014 World Bank data and found no significant correlations between number of PNAs and democracy levels, between social inequality and reduction in the number of PNAs, and between population increases and reduction in the number of PNAs. They observed, however, a significant correlation between Gross Domestic Product (GDP) and number of PNAs. In this sense, Oprsal et al. (2018) conducted cross-sectional regression and panel regression analyses on variables that could influence PNA cover, using data collected between 1990 and 2012. They found that higher economic, social, or institutional development is related to higher proportions of PNA cover, revealing positive trends and important steps towards nature conservation.

The results obtained by Upton et al. (2008) suggested that high-income countries have a higher number of small-sized PNAs than low-income countries but with a higher extent of total protected land than the latter. However, the authors found few significant links between poverty indices and
PNA extent at the national level. On the other hand, Salvio et al. (2016), who correlated the distribution of conservation units with the Municipal Human Development Index (MHDI) and the Gini Index (IGini) of different municipalities of Minas Gerais state (Brazil), observed that IGini varied significantly between municipalities with conservation units and those without them. In other words, what they found is that municipalities with conservation units have higher income concentration, higher social inequality, and thus, higher IGini. They also observed that, in general terms, MHDI neither influences nor is influenced by the existence of conservation units, regardless of their nature, either full protection or sustainable use.

Using socioeconomic development indices, such as the Human Development Index (HDI) and the Gini Index (IGini) can improve our understanding of how PNA goals and management influence PNA surroundings (Salvio, 2017). The HDI was first released in 1990 and broadened the perspective of human development towards incorporating the social dimension (PNUD, 2010). Currently, three principles underpin the HDI: education level, measured through a combination of adult literacy scores (with a $2 / 3$ weight) and school attendance rate combined for primary, secondary, and higher education (with a $1 / 3$ weight); and standard of living measured by real GDP per capita (PNUD, 2010). The IGini is a statistical measure of inequality, developed by the Italian statistician Conrado Gini in 1912, broadly used to indicate the degree of income concentration in a given region. It is based on the Lorenz curve (Hoffmann, 1998) and represented by a number between 0 and 1 , whereby 0 corresponds to perfect income equality and 1 corresponds to perfect income inequality (Hoffmann, 1998). The Gross Domestic Product (GDP) is a synthetic indicator of the economy of a country, state, or city, and consists of the sum of all its goods and services produced in a specific time period, usually one year (IBGE, 2021). Finally, the World Happiness Index (WHI) is generated by the research data gathered for the World Happiness Report, a research conducted in more than 150 countries and based on citizen satisfaction about their own lives. The data are updated annually (World Happiness Report, 2020).

The most comprehensive source of information on the number of terrestrial and marine PNAs and the area covered by them on a global level is the monthly

Revista Árvore 2022;46:e4601 
updated World Database on Protected Areas (WDPA). The WDPA is one of the main global data sources on PNAs and is broadly used by scientists, companies, governments, international secretariats, and others to inform policy planning, decision-making, and management. The WDPA is a joint venture between the United Nations Environmental Programme (UNEP) and the International Union for Conservation of Nature (IUCN). Compilation and management of the WDPA are done by the UN World Conservation Monitoring Centre - WCMC, with the collaboration of governments, non-governmental organizations, academia, and the industry.

The total number of PNAs recorded in the WDPA version released in March 2020 was 248,330, which encompassed 227,090 polygons and 21,240 points covering 245 countries and territories. Most of these areas are located within continents and collectively protect over 20 million $\mathrm{km}^{2}$, which is $15.1 \%$ of the global terrestrial land surface. The marine protected areas (MPAs), despite being lower in number, cover $28,665,325 \mathrm{~km}^{2}$, representing $7.91 \%$ of the global ocean surface. National waters encompass $39 \%$ of the Earth's ocean surface and, currently, $18.40 \%$ of these waters are designated as PNAs. On the other hand, only $1.20 \%$ of the extent of international waters, which make up the remaining $61 \%$ of the global ocean surface, are designated as PNAs. This lower figure among international waters owes to the complex jurisdictional context that affects PNA creation in these waters (WDPA, 2020). The magnitude of these numbers motivates several authors to consider PNAs as the main tool for biological diversity protection. PNA creation and management are important parts of any national environmental policy (Juffe-Bignoli et al., 2014).

Therefore, here we aimed to conduct statistical correlation analyses between PNA existence (as recorded in the WDPA) and the GDP, the HDI, the IGini, and the WHI of their countries of location in a global study.

\section{MATERIAL AND METHODS}

\subsection{Quantitative survey of PNA existence and socioeconomic indicators of each country}

We performed a quantitative survey of PNAs located in 245 countries through the WDPA database (https://www.protectedplanet.net), version released in March 2020. We obtained 2019 GDP data on 200 countries from the official website of the International Monetary Fund (IMF). The HDI and IGini data were surveyed from the Human Development Report published by the Human Development Report Office of the United Nations Development Programme (UNDP), with data collected for 2019 in 176 and 145 countries, respectively. The WHI data were surveyed from the 2019 World Happiness Report (Helliwell et al. 2019) for 156 countries. These were the most upto-date data during the surveys.

We organized the data in a spreadsheet and removed the lines with absent data. This resulted in a list of 145 countries, which composed the study sample.

\subsection{Statistical analyses}

\subsubsection{Sample size assessment}

We performed a sample power analysis through the software GPower v. 3.1.9.4 adopting a significance threshold of 0.05 , which informed that a minimum of 134 observations was needed for a reliable correlation test. The samples evaluated herein were based on at least 145 observations, a number higher than the minimum threshold of 134 (Figure 1).

\subsubsection{Normality test and correlation analyses}

We tested data normality through KolmogorovSmirnov, Lilliefors, and Shapiro-Wilk tests, which

Source: Research data

Fonte: Dados da pesquisa.

\begin{tabular}{|lll|}
\hline$t$ tests - Correlation: Point biserial model & \\
Analysis: & A priori: Compute required sample size \\
Input: & Tail(s) & $=$ Two \\
& Effect size $|\rho|$ & $=0.3$ \\
& $\alpha$ err prob & $=0.05$ \\
& Power $(1-\beta$ err prob) & $=0.95$ \\
Output: & Noncentrality parameter $\delta$ & $=3.6404323$ \\
& Critical t & $=1.9780988$ \\
& Df & $=132$ \\
& Total sample size & $=134$ \\
& Actual power & $=0.9509217$
\end{tabular}

Figure 1 - Result of the sample power analysis (GPower) performed on the data gathered for the correlation analyses between the existence of protected natural areas (PNAs), Gross Domestic Product (GDP), Human Development Index (HDI), Gini Index (IGini), and World Happiness Index (WHI) in 145 countries.

Figura 1 - Resultado do Teste do Poder da Amostra - GPower, realizado a partir dos dados obtidos para correlação estatística entre a existência de Áreas Naturais Protegidas (ANP), Produto Interno Bruto (PIB), Índice de Desenvolvimento Humano (IDH), Indice de Gini (IGini) e Índice Mundial de Felicidade de 145 países. 
informed us that the variables used in this study do not present normal distribution. We then opted for a non-parametric Spearman correlation test, which measures the degree of correlation between two variables (Vieira, 2010) and presents a non-parametric alternative for the Pearson correlation coefficient. The Spearman test must be used when the analyzed variables do not display two-dimensional normal distribution.

Both the Pearson and the Spearman correlation tests measure the degree of linear correlation between

(A)



(C)

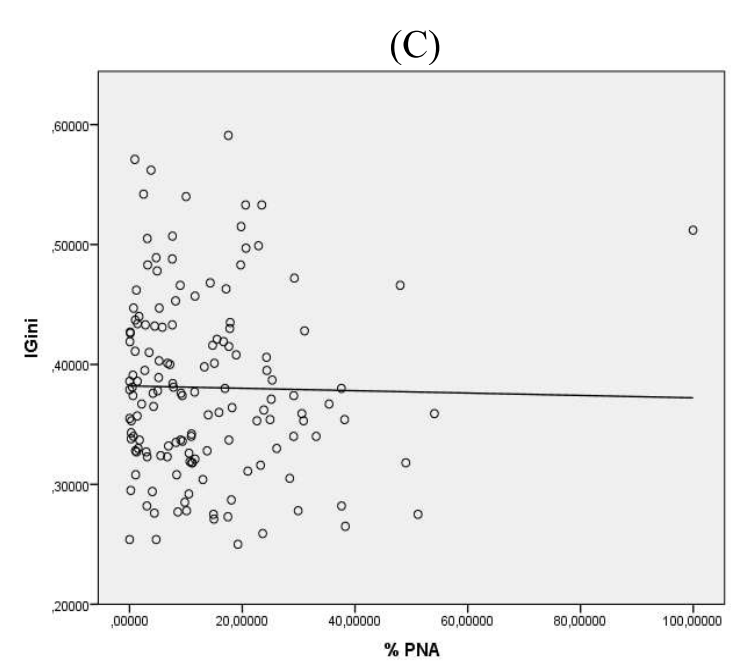

two quantitative variables. But in the Spearman correlation, specifically, the values are transformed into ranks and the correlation represents the linear correlation coefficient of the ranks (Hammer et al., 2001). The results vary between -1 and 1 and, while a value of 0 indicates no linear relationship at all, a value of 1 indicates a perfect linear relationship, and a value of -1 represents a perfect, but inverse, linear relationship, indicating that when one of the variables increases in value, the other decreases. The closest to 1 or -1 , the strongest is the linear association between
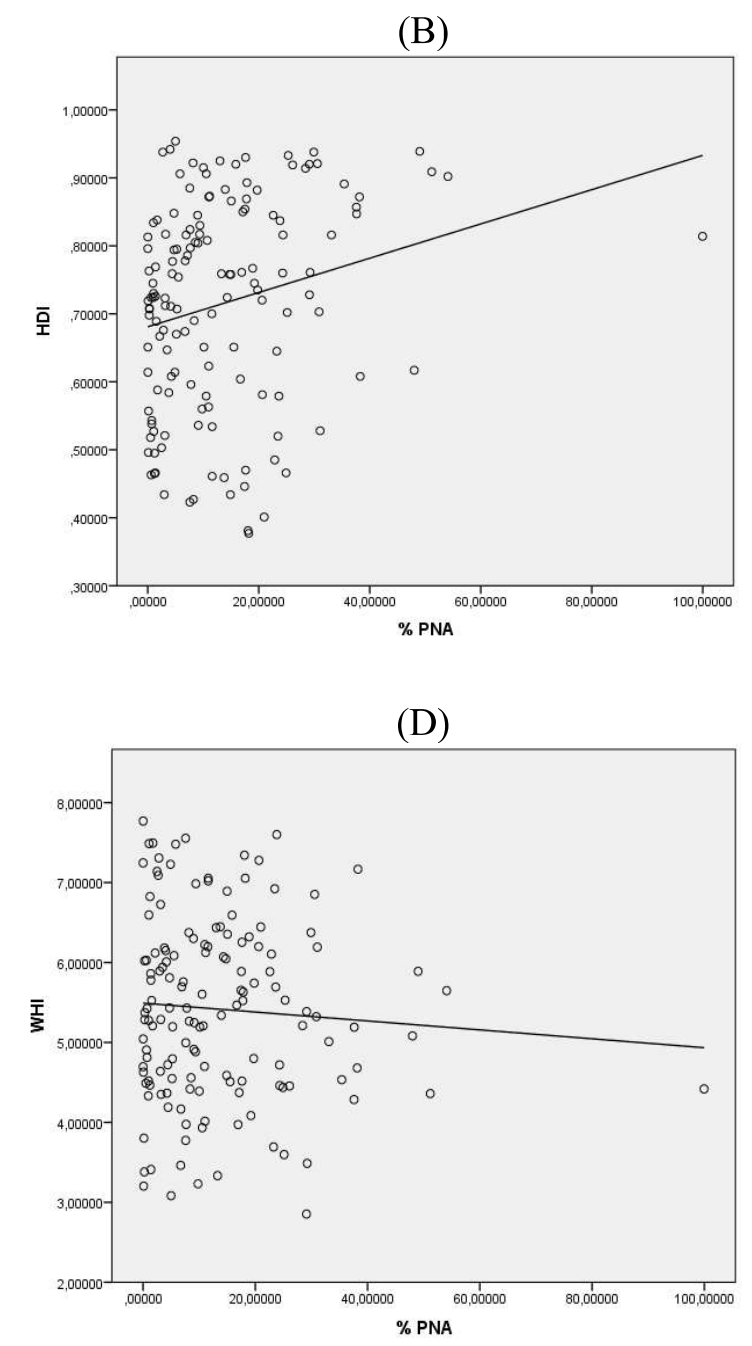

Figure 2 - Correlation between protected natural areas (PNA) and Gross Domestic Product (GDP) (a), Human Development Index (HDI) (b), Gini Index (IGini) (c), and the World Happiness Index (WHI) (d) of 145 countries.

Figura 2 - Correlação entre Áreas Naturais Protegidas (ANP) e o Produto Interno Bruto (PIB) (a), Índice de Desenvolvimento Humano (IDH) (b), Índice de Gini (IGini) (c) e Índice Mundial da Felicidade (IMF) (d) de 145 paises. 
the variables (Hair et al., 2005). The correlation analyses were conducted in software SPSS version 24 .

\section{RESULTS}

We found a positive but non-significant correlation between PNA percentage and GDP (rs $=0.073 ; \mathrm{p}>0.05 ;$ Figure $2 \mathrm{~A}$ ) and a positive and significant correlation between PNA percentage and HDI ( $\mathrm{rs}=0.256 ; \mathrm{p}<0.05$; (Figure 2B). We found a negative but non-significant correlation between PNA percentage and IGini ( $r s=-0.082 ; p>0,05$; Figure 2C). Lastly, we found a negative but non-significant correlation between PNA percentage and WHI ( $\mathrm{rs}=$ $-0.012 ; \mathrm{p}>0.05$; Figure 2D).

These results only revealed a positive and significant correlation between PNA and WHI. No other significant correlation was found between the other indices and the presence or absence of PNAs.

\section{DISCUSSION}

We found a non-significant correlation between PNA percentage and GDP. This result disagrees with Hebron (2018), who observed a statistically significant correlation between GDP and PNA. Our findings also disagree with those by Andam et al. (2010), which indicated that the net impact of environmental protection reduces poverty. Conversely, our results resemble those of Upton et al. (2008), who found few significant relationships between poverty indicators and PNA extent at the national level.

The countries with the highest HDI values also have greater percentages of protected land extent, which suggests that these countries acknowledge the relevance of natural resources and environmental services conservation on guaranteeing the standard of living of their populations. This result is congruent with the findings of Oprsal et al. (2018), who concluded that higher economic, social, or institutional development is linked to higher PNA proportions.

We found a non-significant correlation between PNA percentage and IGini. This result disagrees with the findings of Salvio et al. (2016), which found a positive and significant correlation between the existence of conservation sites and IGini, suggesting that conservation areas in the state of Minas Gerais (Brazil) are linked to greater social disparities, with greater income concentration and social inequality. On the other hand, this result reinforces the observations by Andam et al. (2010) who evidenced that, although communities near PNAs in Costa Rica and Thailand are substantially poorer than the national averages, this analysis does not support the hypothesis that inequality owes to the existence of PNAs.

Our results also suggest that the existence of PNAs does not influence neither is it influenced by the WHI. This finding corroborates the results of Neve and Sachs (2020), who observed that the UN Sustainable Development Goals 14 and 15 present an insignificant correlation with human well-being. Goals 14 and 15 are dedicated to the conservation and sustainable use of, respectively, marine and terrestrial ecosystems. Both feature among the list of 17 sustainable development goals that originated from the United Nations Conference on Sustainable Development that took place in Rio de Janeiro in 2012 aiming to meet urgent global challenges concerning environmental, political, and economic aspects.

According to the World Wide Fund for Nature - WWF (2008), the relationship between PNA and poverty is complex and multifaceted because, while in some cases PNAs have contributed to deepening populations further into poverty, in others, PNAs have had a positive role in poverty reduction. This may be due to the non-significant correlations predominantly found in our analyses, which possibly owe to situational differences among the countries involved in our research. Upton et al. (2008) indeed confirmed that the links between poverty and conservation are dynamic and, often, site-specific; at larger scales, the links between PNA and poverty remained undetermined.

Our results reinforce the WWF (2008) recommendation that site-specific studies be carried out, linking clear PNA management recommendations, local populations, and poverty reduction. Such studies could advance the current understanding of the relationships between PNA management and poverty, as well as evaluate the possibility to replicate a successful management action from one place to another. Besides, good governance is indispensable for attempts to link poverty reduction and PNAs to be successful, reinforcing the perception of PNAs as positive and welcome elements, rather than guarded and threatened sites.

Revista Árvore 2022;46:e4601 


\section{CONCLUSIONS}

Among the studied countries, those with higher HDI levels have also higher percentages of their extent under protection. At the same time, the correlation analyses between the existence of PNAs and GDP, PNAs and IGini, and PNAs and WHI did not produce significant results, which possibly owes to situational differences among the different countries. Regardless, our results allowed us to conclude that PNAs do not necessarily produce poverty. We would encourage future similar studies to segment economically similar countries or regions for a more refined understanding of the links between protected area management and socioeconomic development.

\section{AUTHOR CONTRIBUTIONS}

Ricardo Elói de Araújo: Data collection and organization, bibliographical research, analysis and discussion of results, and article writing.

Helder Antônio da Silva: Designed the methodology, statistics analysis and discussion of results.

Geraldo Majela Moraes Salvio: Conceived the ideas, designed the methodology, analysis and discussion of results.

\section{REFERENCES}

Adams WM, Aveling R, Brockington D, Dickson B, Elliot J, Hutton J, et al. Biodiversity conservation and the eradication of poverty. Science. 2004;306(5699):1146-1149. doi: 10.1126/ science. 1097920

Andam KS, Ferraro PJ, Sims KRE, Healy A, Holland MB. Protected areas reduced poverty in Costa Rica and Thailand. PNAS. 2010;107(22):9996-10001. doi: 10.1073/pnas.0914177107

Araújo MAR. Unidades de conservação no Brasil: da república à gestão de classe mundial. Belo Horizonte: SEGRAC; 2007. ISBN: 9788588669246.

Ávila ES de, Diniz EM. Evidências sobre curva ambiental de Kuznets e convergência das emissões. Estud. Econ. 2015;45(1). doi: 10.1590/01014161201545197ese

Campaign For Nature. Economic benefits of protecting $30 \%$ of planet's land and ocean outweigh the costs at least 5-to-1. Campaign for Nature [Internet]. 2020 [cited 2020 August 8]. Available from: https://www.campaignfornature.org/protecting30-of-the-planet-for-nature-economic-analysis

Canavire-Bacarreza G, Hanauer MM. Estimating the Impacts of Bolivia's protected areas on poverty. World Development. 2013;41:265-285. doi: 10.1016/j.worlddev.2012.06.011

Chechina M, Neveux Y, Parkins JR, Hamann A. Balancing conservation and livelihoods: a study of forest-dependent communities in the Philippines. Conservation \& Society. 2018;16(4):420-430. doi: 10.4103/cs.cs_16_182

Colchester M. Resgatando a natureza: comunidades tradicionais e áreas protegidas. In: Diegues ACS, editor. Etnoconservação da natureza: novos rumos para a proteção da natureza nos trópicos. São Paulo: Hucitec; 2010. p. 225-250. ISBN: 8527105470.

Diegues AC. O mito moderno da natureza intocada. São Paulo: EDUSP; 2001. ISBN: 978-8527103459

Dudley N, editor. Guidelines for Applying Protected Area Management Categories. Gland, Switzerland: IUCN; 2008. doi: 10.2305/IUCN.CH.2008. PAPS.2.en

Ferraro PJ, Hanauer MM, Sims KRE. Conditions associated with protected area success in conservation and poverty reduction. Proceedings of the National Academy of Science of the United States of America. 2011;108(34):13913-13918. doi: 10.1073/pnas. 1011529108

Hair JF, Black WC, Babin BJ, Anderson RE, Tatham RL. Análise multivariada de dados. 5. ed. Porto Alegre: Bookman; 2005. ISBN: 978-8577804023.

Hammer O; Harper DAT, Ryan PD. PAST:

Paleontological Statistics Software Package for Education and Data Analysis. Palaeontologia Electronica. 2001;4(1):1-9.

Hebron M. Conservation Worldwide: an analysis of protected areas under different political systems [thesis]. 2018. Florida: Florida State University; 2018.

Helliwell JF, Huang H, Wang S. Changing World 
Happiness. In: World Happiness Report [Internet]. 2019 [cited 2020 February 15]. Available from: https://s3.amazonaws.com/happiness-report/2019/ WHR19.pdf

Hoffmann R. Distribuição de renda, medidas de desigualdade e pobreza. São Paulo: EDUSP;1998. ISBN: 978-8531404733.

Instituto Brasileiro de Geografia e Estatística - IBGE. [cited 2021 March 11]. Available from: https://www. ibge.gov.br/explica/pib.php

Juffe-Bignoli D, Burgess ND, Bingham H, Belle EMS, Lima MG de, Deguignet M, et al. Global Protected Area Coverage. In: Protected Planet Report. 2014.

Leverington F, Costa KL, Pavese H, Lisle A, Hockings M. A global analysis of protected area management effectiveness. Environmental management. 2010;46(5):685-698. doi: 10.1007/ s00267-010-9564-5

Medeiros R, Young CEF. Contribuição das unidades de conservação brasileiras para a economia nacional Sumário Executivo. Brasília: UNEP-WCMC; 2011.

Naughton-Treves L, Alix-Garcia J, Chapman CA. Lessons about parks and poverty from a decade of forest loss and economic growth around Kibale National Park, Uganda. PNAS. 2011;108(34):1391913924. doi: 10.1073/pnas. 1013332108

Neve JE de, Sachs JD. In: World Happiness Report. 2020 [cited $2021 \mathrm{March} 11$ ]. Available from: https:// happiness-report.s3.amazonaws.com/2020/WHR20. pdf

Oldekop JA, Holmes G, Harris WE, Evans KL. A global assessment of the social and conservation outcomes of protected areas. Conservation Biology. 2016;30(1):133-141. doi: 10.1111/cobi.12568

Oprsal Z, Harmacek J, Pavlík P, Machar I. What factors can influence the expansion of protected areas around the world in the context of international environmental and development goals. Probl. Ekorozw. 2018;13(1):145-157.

Pawlewicz K, Pawlewicz A, Cieślak I. The influence of natura 2000 sites on the investment attractiveness of polish regions. International scientific conference
Rural Development. 2017:721-726. doi: 10.15544/ RD.2017.032

Programa das Nações Unidas para o Desenvolvimento - PNUD. The human development report: the real wealth of nations. New York; 2010. 238 p. ISBN: 978023028445690101

Salvio GMM. Áreas Naturais Protegidas e Indicadores Socioeconômicos: O Desafio da Conservação da Natureza. São Paulo: Paco Editorial; 2017. ISBN: 978-8546207398.

Salvio GMM, Fontes MAL, Silveira-Junior WJ, Silva HA da. Conservation areas, poverty and social inequality: An evaluation using socioeconomic indicators in Minas Gerais, Brazil. Cerne. 2016;22(2):145-150. doi: $10.1590 / 01047760201622022151$

Silveira-Junior WJ, Salvio GMM, Moura AS, Souza CR, Fontes MAL. Payment for environmental services: alleviating the conflict of parks versus people. Journal of Tropical Forest Science. 2020;32(1):8-16. doi:10.26525/jtfs32.1.8

Stevenson TC, Tissot BN, Walsh WJ. Socioeconomic consequences of fishing displacement from marine protected areas in Hawaii. Biological conservation. 2013;160:50-58. doi: 10.1016/j.biocon.2012.11.031

Strassburg BBN, Latawiec AE, Barioni LG, Silva CANVP da, Valentim JF, Vianna M, et al. When enough should be enough: Improving the use of current agricultural lands could meet production demands and spare natural habitats in Brazil. Glob. Environ. 2014;28:84-97. doi: 10.1016/j. gloenvcha.2014.06.001

Tritsch I, Arvor D. Transição na governança ambiental na Amazônia brasileira: surgimento de um novo padrão de desenvolvimento socioeconômico e desmatamento. Política de uso da terra. 2016;59(Suppl. C):446-455.

Upton C, Ladle R, Hulme D, Jiang T, Brockington DE, Adams WM. Are poverty and protected area establishment linked at a national scale? Oryx. 2008;42(1):19-25. doi: 10.1017/S0030605307001044

Vieira S. Bioestatística: tópicos avançados. 3. ed. Rio de Janeiro: Elsevier; 2010. ISBN: 9788535234602. 
World Database on Protected Areas - WDPA. 2020 [cited 2020 May 20]. Available from: https://www. protectedplanet.net/en/resources/march-2020-updateof-the-wdpa

World Wide Fund for Nature - WWF. Protected areas and poverty reduction: A research report by WWF and Equilibrium. 2008 [cited 2020 March 19]. https://www.researchgate.net/ publication/337306764_A_research_report_by_ WWF and Equilibrium the Arguments for Protection_series_SafetyNet_Arguments_for Protection Safety Net Protected areas and poverty reduction A research report by WWF and Equilibriu

Zambrano AMA, Broadbent EN, Durham WH. Social and environmental effects of ecotourism in the Osa Peninsula of Costa Rica: the Lapa Rios case. Journal of Ecotourism. 2010;9(1):62-83. doi: $10.1080 / 14724040902953076$

Zeeshan M, Prusty BAK, Azeez PA. Protected area management and local access to natural resources: a change analysis of the villages neighboring a world heritage site, the Keoladeo National Park, India. Earth Perspectives. 2017;4(2). doi: 10.1186/s40322017-0037-3 